\title{
Effect of Glyphosate Herbicide (360g/l) On Some Biochemical Electrolytes of Exposed Africa Catfish.
}

\author{
*Erhunmwunse, N.O. and Ainerua, M.O \\ Ecophysiology, Ecotoxicology and Pathophysiology Laboratory \\ Department of Animal and Environmental Biology, faculty of Life Sciences, University of Benin, P.M.B 1154, \\ Benin City. Nigeria
}

\begin{abstract}
Assessing the effect of glyphosate herbicide on post Juvenile Africa catfish Clarias gariepinus using specific biochemical markers could provide vital information concerning the health status with regards to electrolyte determination. The sub-lethal effect on biochemical indices of post juvenile C. gariepinus exposed to glyphosate herbicide revealed significant increase $(p<0.05)$ in serum electrolytes, Potassium $\left(K^{+}\right)$, Sodium $\left(\mathrm{Na}^{+}\right)$, Chloride $\left(\mathrm{Cl}^{-}\right)$compared to the control.
\end{abstract}

\section{Introduction}

The assessments of blood biochemical parameters are important to evaluate the health of many vertebrates, including fish (Cnaani et al., 2004; Tavares-Dias et al., 2008). Since blood and biochemical parameters in fish may vary with ambient and other factors (Bentinck-Smith et al., 1987; Tavares-Dias, 2004; Tavares-Dias et al., 2008), they have been used by fish biologists for a variety of purposes, such as detecting cellular damage caused by toxicant exposure, infection by pathogenic agents, and traumatic handling. In addition, the blood biochemical assessments can also be used to evaluate the effects of the diet on liver function, and the osmoregulatory and ion-regulatory functions, effects of sex and maturation cycle and responses to stressors.

In fish, sodium and potassium are predominant electrolytes, with the predominance of sodium in the serum and in other fluids and potassium in extracellular fluids. The main function of proteins and electrolytes, mainly the sodium and potassium, is to regulate the acid-basic balance maintaining thereby an ionic adequacy on the tissue functions (Davis, 2004; Tavares-Dias, 2004; Tavares-Dias et al., 2008).

\section{Fish Sampling}

\section{Materials and Methods}

One hundred and twenty normal post juvenile Clarias gariepinus of both sexes with a mean weight of $135.44 \pm 1.99 \mathrm{~g}$ and mean length of $28.32 \pm 0.844 \mathrm{~cm}$ were purchased from Osayi farms in Benin City, Edo state. They were kept in 601 aquaria at $27.5 \pm 0.4{ }^{\circ} \mathrm{C}, \mathrm{pH} 7.3$, with 12:12 h photoperiod and an average density of 6.4 $\mathrm{g} / \mathrm{l}$. They were left unfed in the first 2 days to adapt to a change in environment before feeding them with the fish diet. Laboratory aquaria were well aerated and provided with external filtration and a layer of gravel on the bottom. Fish were normally fed once a day with pelleted commercial food (Durante Aquaculture fish concentration-2mm). They were allowed to acclimate to captivity conditions for two month prior to taking the blood samples. Careful netting and handling was implemented to minimize stress. The peripheral blood was collected by puncture of the genital opening with a heparin-coated 21 gauge $\times 0.5 \mathrm{in}$. needle, attached to a $2 \mathrm{ml}$ syringe. After sampling, fish were placed in separate tanks of freshwater for recovery.

\section{Biochemical Analysis}

Two fish were removed from the tanks after 7, 14, 21 and 28days of exposure, blood samples were collected from all sampled fish by genital puncture with a $21 \mathrm{~g}$ hypoderm syringe and analyzed for electrolytes.

\section{Result and Discussion.}

Table 1: Mean Value of some serum electrolytes of post juvenile $C$. gariepinus exposed to various concentration of glyphosate herbicide.

\begin{tabular}{llrrr}
\hline Conc. $(\mathbf{m g} / \mathbf{L})$ & Time & Sodium $(\mathbf{m m o l} / \mathbf{d})$ & \multicolumn{1}{c}{ Potassium $(\mathbf{m m o l} / \mathbf{d})$} & \multicolumn{1}{c}{ Chloride $(\mathbf{m m o l} / \mathbf{d})$} \\
\hline $\mathbf{7 2}$ & 7 day & $137.33 \pm 0.667$ & $4.133 \pm 0.0667$ & $110 \pm 1.155$ \\
& 14 day & $139.33 \pm 0.667$ & $5.433 \pm 0.0333$ & $114.67 \pm 0.333$ \\
& 21 day & $138.67 \pm 0.677$ & $6.933 \pm 0.0333$ & $121 \pm 0.577$ \\
& 28 day & $145.00 \pm 0.577$ & $8.2 \pm 0.1155$ & $117.33 \pm 0.667$
\end{tabular}




\begin{tabular}{|c|c|c|c|c|}
\hline \multirow{4}{*}{54} & 7 dav & $136.33 \pm 0.333$ & $4.167 \pm 0.0882$ & $110.67 \pm 0.667$ \\
\hline & 14 day & $139.33 \pm 0.667$ & $5.467 \pm 0.0667$ & $116 \pm 1.155$ \\
\hline & $21 \mathrm{day}$ & $137.33 \pm 0.667$ & $5.667 \pm 0.0667$ & $116 \pm 1.155$ \\
\hline & 28 day & $137.33 \pm 0.667$ & $7.233 \pm 0.0333$ & $117.33 \pm 0.667$ \\
\hline \multirow[t]{4}{*}{32} & 7 day & $138.67 \pm 1.764$ & $4.467 \pm 0.0333$ & $107.33 \pm 0.667$ \\
\hline & 14 day & $138.67 \pm 0.667$ & $5.1000 \pm 1.00$ & $120.67 \pm 0.667$ \\
\hline & 21 day & $138.00 \pm 1.155$ & $5.133 \pm 0.0667$ & $116.67 \pm 0.677$ \\
\hline & 28 day & $141.33 \pm 2.404$ & $7.2 \pm 0.0577$ & $106 \pm 0.577$ \\
\hline \multirow{4}{*}{18} & 7 day & $134.67 \pm 0.667$ & $4.767 \pm 0.0882$ & $116 \pm 0.577$ \\
\hline & 14 day & $137.33 \pm 0.667$ & $6.5 \pm .0 .0577$ & $109 \pm 0.577$ \\
\hline & 21 day & $134.67 \pm 0.667$ & $4.967 \pm 0.0882$ & $115.67 \pm 0.882$ \\
\hline & 28 day & $138 \pm 0.575$ & $6.533 \pm 0.0667$ & $113.67 \pm 0.882$ \\
\hline
\end{tabular}

The result of Sodium $(\mathrm{Na}+)$ showed a significant difference $(\mathrm{p}<0.05)$ in all fish exposed to various concentration of glyphosate. The levels of sodium gradually increased during prolonged toxic exposure time periods to glyphosate. Sodium is the chief regulator of osmotic pressure of the body fluid. It initiates and maintains the contraction of heart and involuntary muscles and excites the nerves. Eisler and Edmunds (1966) observed an increased concentration of sodium in blood and decreased levels in the liver of the marine fish, northern puffers Sphaeroides maculates, on exposure to lethal concentration of endrin. The result from this study disagrees with the findings of Shastry and Dasgupta, (1991) who recorded a significant decline in sodium ion concentration in liver and muscle of Channa punctatus exposed to $1 \mathrm{ppm}$ of nuvacron for 60 days.

According to Bradifield and Rees (1978), toxicants act by disruption of cell membrane permeability replacing the structural or electrochemical important elements in the cell which cause functional failure. Sodium and potassium are the major cations of the extracellular fluid and chloride being the major anion of the intracellular fluid (Adegoye, 2007). The levels of sodium and potassium ions in the selected organs and tissue of $H$. bidorsalis were either higher or lower than the control value- a reflection of changes in the fluxes of these electrolytes as a result of cypermethrin toxicosis. Sodium and potassium are essential for the activity of many enzymes and have been implicated in the transport of ATP which participates in several metabolic processes. $\mathrm{Na}+$ and $\mathrm{K}+$ ATpase, are located in the cell membrane has been found to be involved in the active transport of $\mathrm{Na}+$ and $\mathrm{K}+$ across the cell membrane (Rajanna et al., 1981). The increased level of ion in the blood could be attributed to the observed alterations in the organs of $C$. gariepinus and correspond with the observation of Oluwole (2001) who stated that ions may indicate damage to the gills and the kidney.

Reduction of $\mathrm{Na}+$ ion level may affect the heart functions of experimental fish and cause neurotoxic damage to the central nervous system (CNS) of the experimental fish (Luskova et al., 2002). Changes in these ions may be an indication of the disruption of the structural integrity of the gills and impending death under prolonged exposure to the chemicals.

Chloride ion as the major extracellular fluid in the body combines with sodium to form $\mathrm{NaCl}$ (sodium chloride) which then helps in the osmotic balance of the organism (Adeoye, 2007). Increase or decrease $\mathrm{Cl}^{-}$ion has been associated with handling stress

(Tomasso et al., 1980) and kidney disease. A mild decrease in chloride ion has been attributed to gill injury (Byme et al., 1989) and loss of chloride across the gills due to damage from toxicant exposure. Increase chloride may also arise from over-activity of the parathyroid glands.

The levels of chloride significantly increased $(\mathrm{P}<0.05)$ during prolonged toxic exposure periods of glyphosate herbicide to C. gariepinus. Chloride ions along with sodium and potassium play an important role in neuromuscular excitability, acid base balance and osmotic pressure of the body. A biphasic response in blood chloride concentration has been reported in fishes subject to various concentrations of insecticides. Eisler and Edmunds (1966) observed hyper and hypochloremia in the northern puffer exposed to different doses of endrin.

In the same species, (Misra and Srivastava, 1983, 1984) recorded both hyperchloremia and hypochloremia at different time intervals of acute exposure of the fish to triazophos respectively. Acute stress of insecticides causes diuresis in fishes and a severe loss of water and electrolytes due to increased GFR and deficient tubular reabsorption (Hickman and Trump, 1969). 


\section{Conclusion}

The increased concentration of electrolytes in the serum of exposed fish showed that the fish responded to the stress condition in the environment caused by the presence of glyphosate and as such should such serum electrolyte should be monitored as slight changes in the environment could alter their quantity.

\section{References}

[1]. Adeoye A. (2007). A Testbook for Medical laboratory Practice. 1st Edition. 238pp.

[2]. Beninck-Smith, J.; Beleau, M.H.; Waterstrat, P.; Tucker, C.S.; Stiles, F.; Bowser, P.R and Brown, L.A. (1987). Biochemical reference ranges for commercially reared channel catfish. The Progressive Fish-Culturist, 49:108-1147.

[3]. Bradifield, R.E. and Rees, C.E. (1978). The impact of toxic pollutants. Effluents and Water Treatment Journal, 18:61-81.

[4]. Byme, P., Speare, D. and Ferguson, H.W. (1989). Effects of cationic detergent on the gills and blood chemistry of rainbow trout, Salmon gairdneri. Dis. Aquat. Org., 61:185-196.

[5]. Cnaani A, Tinman b, Advidar Y, Ron M, Hulate G (2004) Comparative Study of Biochemical parameters in response to stress in O. aureus, O. Mossambicus and two strains of O. Silaticus. Aquaculture, 35: $1434-1440$.

[6]. Davis, K. (2004). Temperature affects physiological stress response to acute confinement in sunshine bass (Morone chrysops and Morone saxatilis). Comparative Biochemistry and Physiology, 139(A):433-440.

[7]. Eisler, R. and P.H. Edmunds (1966). Effect of endrin on blood and tissue chemistry of a marine fish. Trans. Am. Fish. Soc., 95: 153-159.

[8]. Luskova, V., Svoboda, M. and Kolarova, J. (2002). The effect of diazinon on blood plasma biochemistry in Carp (Cprinus carpio L.). Acta Vet. Brno., 71:117-123.

[9]. Mishra, J. And Srivastava, A. K. (1983). Malathion induced hematological and biochemical changes in the Indian catfish Heteropneutes fossilis. Environ. Res., 30:393- 398.

[10]. Oluwole, S.F. (2001). Effects of garlic on some haematological and biochemical parameters. African Journal of Biomedical Research, 4:139-141

[11]. Rajanna, B., Chapatwala, K.D., Vaishnav, D.D. and Desaiah, D. (1981). Changes in ATpase activity in tissues of rat fed on cadmium. J. Environ. Biol., 2(1):1-9.

[12]. Shastry, K.V. and A. Dasgupta, (1991). Effect of nuvacron on the nutritive value of freshwater teleost fish, Channa punctatus. J. Environ. Biol., 12(3): 243-248.

[13]. Tavares-Dias, M. (2004). Características bioquímicas de Brycon cephalus e Brycon orbignyanus, teleósteos dulciaqüícolas brasileiros de importância econômica. pp. 282-285. Disponível em: 〈http// www.civa2004.org/>.

[14]. Tavares-Dias, M., Moraes, F.R and Imoto, M.E. (2008). Haematological parameters in two neotropical freshwater teleost, Leporinus macrocephalus (Anostomidae) and Prochilodus lineatus (Prochilodontidae). Bioscience Journal, 24:96-101

[15]. Tomasso, J.R., Davis, K.B. and Parker, N.C. (1980). Plasma Corticosteroid and electrolyte dynamics of hybrid striped bass (White bass and striped bass) during netting and hauling. Proc.World Maricult. Soc., 1:303-310. 